\title{
Effect of Colchicine on the Depletion and Replenishment of Cytoplasmic Glucocorticoid Receptor in Rat Liver after Administration of Glucocorticoid
}

\author{
ShOGo ICHII AND AKIO YOSHIDA* \\ Division of Physiology, Institute of Steroid Research, and 1st Department of \\ Internal Medicine,* Tottori University School of Medicine, Yonago, 683
}

\begin{abstract}
Pretreatment of rats with colchicine $(3 \mathrm{mg} / \mathrm{kg}$ body weight) modified the time course of depletion of the cytoplasmic binding sites for ${ }^{3} \mathrm{H}$-dexamethasone after administration of prednisolone $(0.5$ or $1.5 \mathrm{mg} / \mathrm{kg}$ body weight). Colchicine also decreased the rate of the cytoplasmic receptor replenishment which was confirmed by application of this drug after completion of the cytoplasmic receptor translocation to nuclei (30 min after prednisolone injection). Addition of colchicine to the incubation mixture for in vitro binding of ${ }^{3} \mathrm{H}$-dexamethasonelabelled liver cytosol to isolated liver nuclei suspended in TKMS buffer (50 $\mathrm{mM}$ Tris- $\mathrm{HCl}, \mathrm{pH} 7.5,50 \mathrm{mM} \mathrm{KCl}, 5 \mathrm{mM} \mathrm{MgCl} 2$ and $250 \mathrm{mM}$ sucrose) evoked no measurable changes in the rate of the nuclear binding.
\end{abstract}

Schum and Webb (1974) reported that colchicine inhibited the transport of RNA from nucleus to cytoplasm in rat liver in vivo. The inhibition was also evident in vitro only if the isolated nuclei were stabilized in the fortified medium (Schum and Webb, 1974). This inhibitory effect of colchicine on the RNA transport was attributed to the constriction of the pore-complexes in the nuclear periphery (Agutter and Suckling, 1982). Translocation of steroid hormones to the nucleus after binding to cytoplasmic receptor is a necessary step (Edelman, 1975, Gorski and Gannon, 1976) and the replenishment of cytoplasmic receptors after translocation also seems to play an important role (Izawa

\section{Received July 30, 1984}

Trivial names used; dexamethasone; $9 \alpha$-fluoro$11 \beta, 17 \alpha, 21$-trihydroxy-16a-methyl-1, 4-pregnadiene-3, 20-dione, prednisolone; 11 $, 17 \alpha, 21-$ trihydroxypregna-1, 4-diene-3, 20-dione et al., 1982) in the action of steroid hormones. The replenishment of cytoplasmic receptors after depletion by steroid hormone administration has been mainly attributed to cycling of the translocated receptors to the cytoplasm (Ishii et al., 1972, Ichii, 1981), but conflicting results, in which net synthesis of the receptor protein is responsible, have been reported (Jungblut et al., 1979, Mester and Baulieu, 1975). However, precise sequences of the cytoplasmic receptor depletion and replenishment following hormone treatment have not been fully elucidated and problems in receptor dynamics have not yet been solved.

In the present study, the effect of colchicine on the depletion and replenishment of the cytoplasmic glucocorticoid receptors after administration of glucocorticoid was examined in the hope of shedding light on the mechanism of translocation to nuclei, 
cycling to the cytoplasm and also on the possible interaction with nuclear components of glucocorticoid receptors.

\section{Materials and Methods}

\section{Chemicals}

$\left[1,2,4-^{3} \mathrm{H}\right.$-Dexamethasone (specific radioactivity, $42 \mathrm{Ci} / \mathrm{mmole}$ ) was purchased from Amersham Internatl. Ltd. (Amersham, UK). Prednisolone and colchicine were obtained from Nakarai Chenical Co. (Kyoto, Japan). Other chemicals used were of analytical grade.

\section{Animals and preparation of cytosols and nuclei \\ Male Wistar rats weighing $150-160 \mathrm{~g}$ were adrenalectomized and used for experiments be- tween 7 and 9 days post operation. In the present study prednisolone was chosen to deplete the cytoplasmic receptors because, with this steroid, replenishment of the cytoplasmic receptor took place promptly (Ichii, 1981) and this allowed us to examine the process of receptor dynamics within a relatively shorl period. Prednisolone was dissolved in $0.2 \mathrm{ml}$ of $30 \%$ ethanol-saline solution and administered subcutaneously at the interscapular region of recipient animals. Colchi- cine was similarly administered at the sacral region as $0.2 \mathrm{ml}$ of the saline solution. Animals were sacrificed by decapitation and livers were perfused in situ with isotonic saline via the portal vein. To prepare cytosols, livers were homo- genized in 3 volumes ice-cold buffer solution which consisted of $15 \mathrm{mM}$ of Tris- $\mathrm{HCl}(\mathrm{pH} 7.4), 0.5 \mathrm{mM}$ EDTA and $2 \mathrm{mM}$ 2-mercaptoethanol (TEM buffer). Homogenates were centrifuged at 800 $\times \mathrm{g}$ for $10 \mathrm{~min}$ followed by $105,000 \times \mathrm{g}$ for $1 \mathrm{hr}$. After the centrifugation, the lipid layer was removed and the clear supernatant was used as cytosols. For isolation of liver nuclei, tissues were homogenized in 2 volumes of isotonic buffered solution which contained $50 \mathrm{mM}$ Tris- $\mathrm{HCl}(\mathrm{pH} 7.5), 50 \mathrm{mM} \mathrm{KCl}, 5 \mathrm{mM} \mathrm{MgCl}_{2}$ and $250 \mathrm{mg}$ sucrose (TKMS buffer). The homogenate was centrifuged at $1,000 \times \mathrm{g}$ for $10 \mathrm{~min}$ and purification of the crude nuclear fraction was carried out according to the method of Blobel and Potter (1966) using $2.0 \mathrm{M}$ buffered sucrose as a cushion. Purified nuclei were further washed twice with the TKMS buffer before use.}

Assay of ${ }^{3} \mathrm{H}$-dexamethasone binding in cytosols

Prior to incubation, cytosols were treated with $1 / 5$ volume of dextran charcoal (DCC, 0.25 $\%-2.5 \%$ in TEM buffer) at $0^{\circ} \mathrm{C}$ for $10 \mathrm{~min}$ to remove free steroids. This treatment did not cause any measurable change in the binding capacity of cytosols prepared from the liver of uninjected animals. After centrifugation at 3,000 $\times \mathrm{g}$ for $5 \mathrm{~min}$ to remove charcoal, duplicate aliquots of the treated cytosol (approx $3 \mathrm{mg}$ as protein) were incubated with $30 \mathrm{nM}{ }^{3} \mathrm{H}$-dexamethasone in the presence or absence of 500 -fold molar excess of unlabelled dexamethasone in a final volume of $0.4 \mathrm{ml}$ at $0^{\circ} \mathrm{C}$ for $16 \mathrm{hr}$. At the end of the incubation period, the reaction mixtures were mixed with $0.2 \mathrm{ml}$ of the DCC, left at $0^{\circ} \mathrm{C}$ for $15 \mathrm{~min}$, centrifuged twice at $3,000 \times \mathrm{g}$ for $5 \mathrm{~min}$ and the radioactivity in an aliquot of the supernatant was measured. The radioactivity in the protein bound fraction which was not displaced by the addition of a 500 -fold molar excess of the unlabelled dexamethasone was subtracted to calculate the specific binding. Under these incubation conditions $85-90 \%$ of the binding sites which were occupied by unlabelled prednisolone during the period of preincubation $\left(6 \mathrm{hr}\right.$ at $\left.0^{\circ} \mathrm{C}\right)$ were displaced with ${ }^{3} \mathrm{H}$-dexamethasone.

Determination of nuclear binding of ${ }^{3} \mathrm{H}$-dexamethasone-labelled cytosol

Cytosols were incubated as described above in the presence of ${ }^{3} \mathrm{H}$-dexamethasone $(30 \mathrm{nM})$ and after removing unbound ligand with DCC, sucrose, $\mathrm{KCl}$ and $\mathrm{MgCl}_{2}$ were added to make the concentrations $250 \mathrm{mM}$ (sucrose), $50 \mathrm{mM}$ $(\mathrm{KCl})$ and $5 \mathrm{mM}\left(\mathrm{MgCl}_{2}\right)$, respectively. Nuclei (approx $250 \mu \mathrm{g}$ as DNA) were suspended in 0.5 $\mathrm{ml}$ TKMS buffer which contained ${ }^{3} \mathrm{H}$-dexamethasone-labelled cytosol $(58,000 \mathrm{dpm}, 1.6 \mathrm{mg}$ as protein) and incubated at $25^{\circ} \mathrm{C}$ for $30 \mathrm{~min}$. After the incubation $2.0 \mathrm{ml}$ of ice-cold TKMS buffer was added and nuclei were recovered by centrifugation at $1,000 \times \mathrm{g}$ for $5 \mathrm{~min}$. The precipitated nuclei were further washed twice with $1 \mathrm{ml}$ of the same buffer and then the nuclear bound ligand was extracted with $0.5 \mathrm{ml}$ of ethanol twice to determine the radioactivity.

\section{Analytical methods}

Protein and DNA were determined by the methods of Lowry et al. (1951) and Burton (1968), respectively. Radioactivity was determined in a liquid scintillation spectrometer (Aloka-LSC 700) with automatic standardization for quenching correction. 


\section{Results}

Effect of pretreatment of animals with colchicine on ${ }^{3} \mathrm{H}$-dexamethasone binding sites of liver cytosol after administration of prednisolone

Injection of prednisolone $(0.5$ or $1.5 \mathrm{mg} /$ $\mathrm{kg}$ body weight) to adrenalectomized rats led to a rapid reduction in ${ }^{3} \mathrm{H}$-dexamethasone binding in liver cytosols (Fig. Ia and b). At 30 min after the injection, the shortest period examined, depletion of the cytoplasmic binding sites for ${ }^{3} \mathrm{H}$-dexamethasone was maximum and a rapid replenishment of the binding site took place in the following period. The rate of depletion depended on the dose administered (compare Fig. la and $b$ ) but the binding sites in the cytosol had returned almost to the uninjected control level by $7 \mathrm{hr}$ postinjection. A decrease in the level of ${ }^{3} \mathrm{H}$-dexamethasone binding observed in the animals receiving prednisolone injection was not attributable to the apparent loss of the binding sites due to occupation of the receptors by the administered steroid, since under incubation conditions used for determination of ${ }^{3} \mathrm{H}-$-dexamethasone binding $\left(0^{\circ} \mathrm{C}\right.$ for $\left.16 \mathrm{hr}\right)$, most of the pre-bound prednisolone was displaced with ${ }^{3} \mathrm{H}$-dexamethasone in the incubation mixture (see the Materials and Methods).

Fig. 1. Effect of colchicine on the depletion and replenishment of cytoplasmic glucocorticoid receptor of the liver after administration of prednisolone to adrenalectomized rats.

Colchicine ( $3 \mathrm{mg} / \mathrm{kg}$ body weight) dissolved in $0.2 \mathrm{ml}$ of saline was injected subcutaneously at the

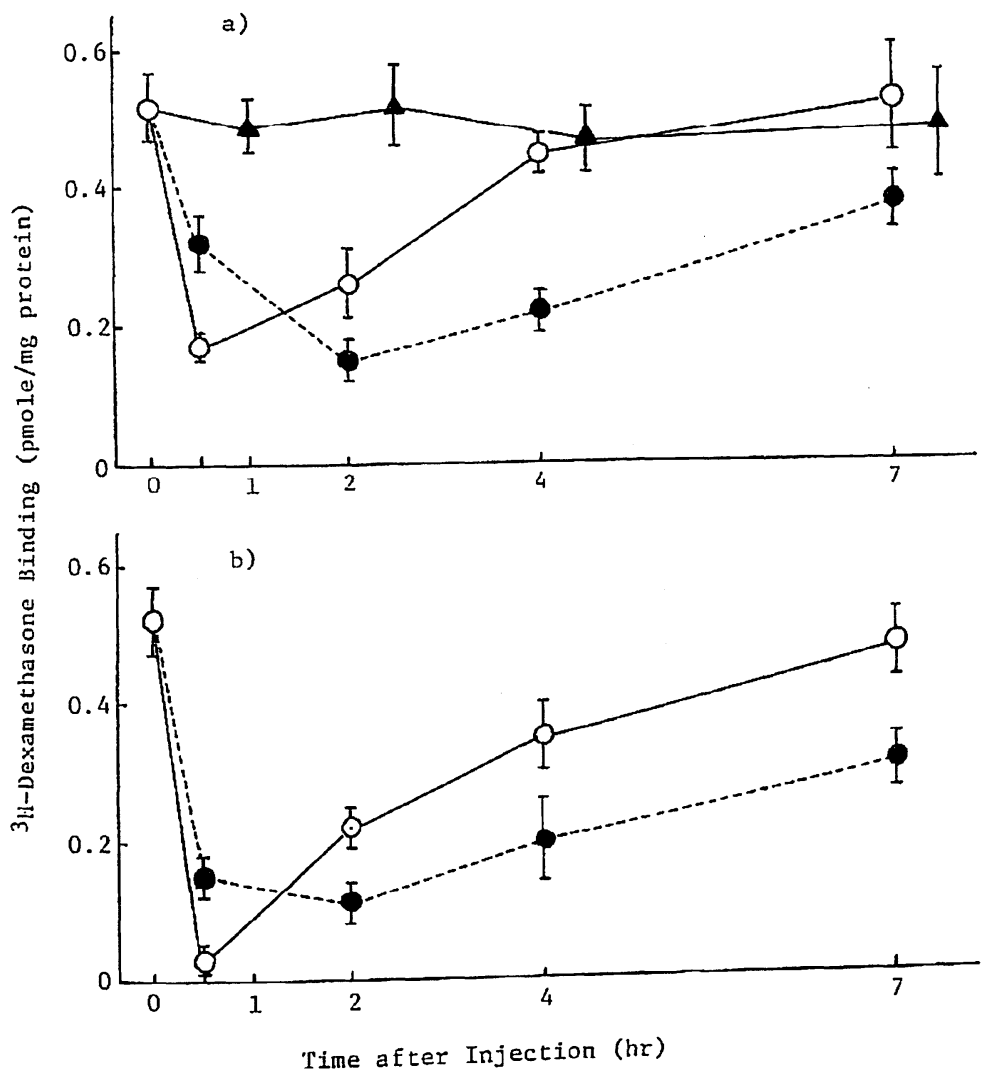

sacral region. Prednisolone $(0.5 \mathrm{mg}$ in a and $1.5 \mathrm{mg}$ in $\mathrm{b} / \mathrm{kg}$ body weight) dissolved in $0.2 \mathrm{ml}$ of $30 \%$ ethanolsaline was injected subcutaneously at the interscapular region $30 \mathrm{~min}$ after colchicine administration. The same amount of the vehicles was administered similarly to rats received colchicine or prednisolone alone. At the indicated times, animals were sacrificed and ${ }^{3} \mathrm{H}-$ dexamethasone binding in liver cytosols was measured as described in the "Methods." Each point represents mean $\pm S E M$ of experiments using at least 5 rats. Results of colchicinetreated prednisolone-injected rats were depicted based on the time of prednisolone injection. $\bigcirc$ Prednisolone alone Colchicine-prednisolone $\Delta$ Colchicine alone 
Pretreatment of animals with colchicine modified the time course of receptor depletion and replenishment, and maximum depletion was observed $2 \mathrm{hr}$ after administration of prednisolone when replenishment of the binding site in the cytosol was apparently observed in the animals that received prednisolone alone. With a larger dose of prednisolone $(1.5 \mathrm{mg} / \mathrm{kg}$ body weight), the cytoplasmic binding sites for ${ }^{3} \mathrm{H}$-dexamethasone disappeared almost completely but pretreatment of animals with colchicine prevented the complete loss of the binding sites, approximately $30 \%$ of the binding sites remaining in the cytosol (Fig. 1b).

The rate of replenishment of the binding sites was significantly low in the colchicine treated animals throughout the experimental period but administration of colchicine alone did not alter the level of cytoplasmic binding site at any time after the administration.

Depletion of the cytoplasmic receptor after hormone administration has been explained by translocation of the steroid hormone-receptor complexes to nuclei in various tissues (Mester and Baulieu, 1975, Anderson et al., 1975, Van Doorn and Bruchovski, 1978, Jungblut et al., 1979, Bloom et al., 1980, Izawa et. al., 1982, Schmidt and Litwack, 1982) and for the mechanism of replenishment, recycling of the translocated receptors to the cytoplasm has been proposed (Izawa et al., 1982, Schmidt and Litwack, 1982). To examine whether the low rate of replenishment is merely the result of a decreased rate of nuclear translocation or whether colchicine induces changes in the process of replenishment also, colchicine was administered 30 $\mathrm{min}$ after prednisolone injection $(1.5 \mathrm{mg} / \mathrm{kg}$ body weight) when the cytoplasmic binding site was depleted to a negligible level. As shown in Table 1 , the replenished binding sites were significantly lower in the colchicine administered animals and this clearly indicated that colchicine may also influence the process of releasing the receptor from
Table 1. Effect of colchicine on the replenishment of binding sites for ${ }^{3} \mathrm{H}$-dexamethasone in liver cytosols after depletion by administration of prednisolone.

\begin{tabular}{|c|c|c|}
\hline \multirow[b]{2}{*}{ Treatment } & \multirow[b]{2}{*}{ No of Animals } & Binding Sites \\
\hline & & $\begin{array}{l}\text { (pmole/mg } \\
\text { protein)* }\end{array}$ \\
\hline Prednisolone & 8 & $0.379 \pm 0.038$ \\
\hline $\begin{array}{l}\text { Prednisolone } \\
\quad+\text { Colchicine }\end{array}$ & 7 & $0.214 \pm 0.025$ \\
\hline
\end{tabular}

All animals received prednisolone $(1.5 \mathrm{mg} /$ $\mathrm{kg}$ body weight) and were divided into two groups. Animals in one group received saline and to the others colchicine $(3 \mathrm{mg} / \mathrm{kg}$ body weight) was injected $30 \mathrm{~min}$ after predisolone injection. Animals were sacrificed $3.5 \mathrm{hr}$ after the 2nd injection and binding sites for ${ }^{3} \mathrm{H}$-dexamethasone in the liver cytosols were determined as described in the "Methods." The difference between the binding sites in these two experimental groups is statistically significant $(\mathrm{P}<0.005)$. * Mean \pm SEM

the nuclei.

Effect of colchicine on the binding of ${ }^{3} \mathrm{H}$ dexamethasone-receptor complexes to nuclei in vitro

The depletion of the cytoplasmic receptors after hormone administration is attributable to the translocation of hormone receptor complexes to nuclei. The effect of colchicine on the rate of binding of ${ }^{3} \mathrm{H}$-dexamethasone-labelled cytosol to isolated nuclei was therefore examined in vitro. No significant effect of colchicine was observed even with high concentrations under conditions used for isolation of nuclei and incubation (Fig. 2).

\section{Discussion}

Colchicine is well known to disrupt microtubules (Wilson et al., 1974), but its effect on the nuclear transport system is explained by the fact that colchicine binds to the 


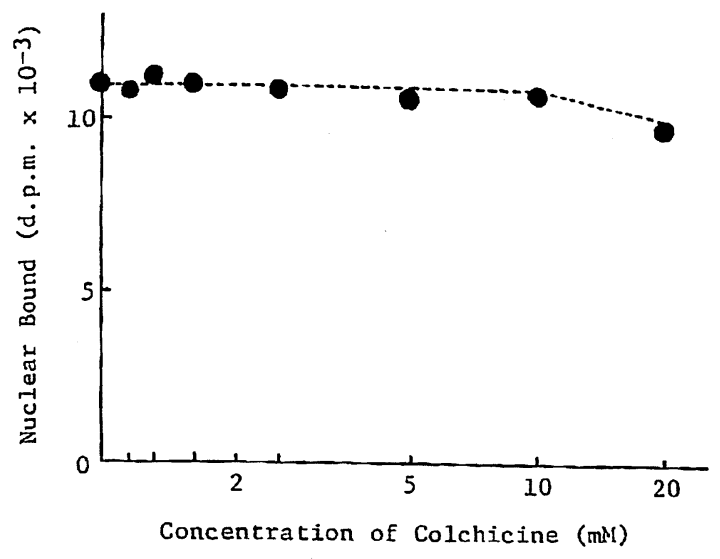

Fig. 2. Effect of colchicine on the nuclear binding of ${ }^{3} \mathrm{H}$-dexamethasone-receptor complexes in vitro.

Purified nuclei were suspended in $0.4 \mathrm{ml}$ TKMS buffer and preincubated in the presence of various concentrations of colchicine at $0^{\circ} \mathrm{C}$ for $15 \mathrm{~min}$. At the end of the preincubation period, $0.1 \mathrm{ml}$ of ${ }^{3} \mathrm{H}$ dexamethasone-labelled cytosol $(58,800$ d.p.m., $1.6 \mathrm{mg}$ as protein) was added and incubation was continued at $25^{\circ} \mathrm{C}$ for 30 min. After the incubation, the nuclei were washed with the TKMS buffer 3 times and the nuclear bound radioactivity was measured. For other details of the experimental conditions, see the "Methods."

nuclear envelope and causes some structural changes in the pore-complexes (Agutter and Suckling, 1982). The pore-complexes are generally held to be the sites of macromolecular exchange between nucleus and cytoplasm (Schum and Webb, 1974), so that the inhibition of nuclear translocation of receptor complexes and replenishment of cytoplasmic receptors observed in the present study may indicate the involvement of the nuclear envelope in events which lead to the biological action following administration of steroid hormones. Since compounds that interfere with microtubules or microfilaments, such as cytochalasine or vinblastin, were shown to have no measurable effect on the receptor translocation in the uterus of estrogen-treated rats (Gorski and Raker,
1973) and the evidence that the nuclear envelope contained no tubulin has been proposed (Agutter and Suckling, 1982), as pointed out previously by Gorski and Raker (1974), the participation of microtubulues in the intracellular movement of steroid hormore receptors seems less likely.

As to the mechanism of receptor replenishment in the cytoplasm, new receptor synthesis was mainly attributed in the estrogen receptor system (Mester and Baulieu, 1975, Sarff and Gorski, 1971, Korach and Ford, 1978, Jungblut et al., 1979), while the major role of cycling of the translocated receptors to the cytoplasm was postulated by others in the glucocorticoid receptor system (Ishii et al., 1972, Aronow, 1978, Ichii, 1981, Schmidt and Litwack, 1982). Administration of colchicine after completion of receptor translocation delays the appearance of the receptors in the cytoplasm (Table 1). It is quite probable that the rate of new receptor synthesis is depressed to some extent by inhibition of RNA release from nuclei by colchicine, but together with the observation that administration of cycloheximide does not modify the pattern of receptor replenishment (Ichii, 1981), the results obtained in the present study strongly suggest the interaction of receptors with nuclear envelopes during the process of receptor replenishment, at least in the receptor system for glucocorticoid of the rat liver. In this respect, the findings of the present study are at variance with those of Farman et al. (1984), King and Greene (1984) and Welshones et al. (1984). These investigators claimed in the study of mineral corticoid receptor in the rabbit kidney and of estrogen receptor in the tumor cells that the unfilled receptors as well as filled ones reside exclusively in the nuclear compartment. If this is the case with the glucocorticoid receptor in the rat liver also, the interaction of receptors with the nuclear envelope should not be involved.

Colchicine does not inhibit the in vitro 
binding of ${ }^{3} \mathrm{H}$-dexamethasone-receptor complexes to nuclei suspended in the simple TKMS buffer. This is analogous to the transport of RNA from nuclei where the inhibitory effect of colchicine is observed only if the isolated nuclei are stabilized in the specifically fortified medium (Schum and Webb, 1974, Agutter and Suckling, 1982). Many investigations including some performed in this laboratory used the nuclear binding of steroid hormone-receptor complexes in vitro in unfortified media as a model system of the nuclear translocation but it does not mimic the in vivo situation in regard to the insensitivity to colchicine. Attempts to develop a colchicine sensitive in vitro system for binding of receptor complexes to nuclei, which will allow us to examine the process of translocation to and release from nuclei of steroid hormone receptors in vitro, are under way in this laboratory.

It is widely accepted that most of steroid hormones act by the same intracellular mechanism (Edelman, 1975, Mainwaring, 1975, Gorski and Gannon, 1976, O'Malley et al., 1976). It will have to be examined whether or not the interaction of steroid hormone-receptor complexes of the nuclear envelope is one of the general sequences in the action of steroid hormones in various target tissues.

\section{References}

Agutter, P. S. and K. E. Suckling (1982). Effect of colchicine on mammalian liver nuclear envelope and on nucleo-cytoplasmic RNA transport. Biochim. Biophys. Acta, 698, 223-229.

Anderson, J. N., E. J. Peck and J. H. Clark (1975). Estrogen-induced uterine responses and growth: Relationship to receptor estrogen binding by uterine nuclei. Endocrinology, 96, 160-167.

Aronow, L. (1978). The glucocorticoid receptor of mouse fibroblast. Fed. Proc., 37, 162-167.

Blobel, G. and V. R. Potter (1966). Nuclei from rat liver: Isolation method that combines purity and high yield. Science, 154, 1662-1665.
Bloom, E., D. T. Matulich, N. C. Lan, S.J. Higgins and G. M. Tomkins (1980). Nuclear binding of glucocorticoid receptor: Relations between cytosol binding, activation and the biological responses. J. Steroid Biochem., 12, 175-184.

Burton, K. (1963). Determination of DNA concentration with diphenylamine. Meth. Enzymol. XII, Part B, 163-166.

Edelman, I.S. (1975). Mechanism of action of steroid hormones. J. Steroid Biochem., 6, 147159.

Gorski, J. and F. Gannon (1976) Current models of steroid hormone action: A critique. Ann. Rev. Physiol., 38, 425-450.

Gorski, J. and B. Raker (1973). The effect of cytocharasin B on estrogen binding and 2deoxyglucose metabolism in the rat uterus. Endocrinology, 93, 1212-1216.

Ichii, S. (1981). Depletion and replenishment of glucocorticoid receptor in cytosols of rat tissues after administration of various glucocorticoids. Endocr. Jpn., 28, 293-304.

Ishii, D. N., W. B. Pratt and L. Aronow (1972). Steady state level of the specific glucocorticoid binding component in mouse fibroblasts. Biochemistry, 11, 3896-3904.

Izawa, M., A. Yoshida and S. Ichii (1982). Dynamics of glucocorticoid receptor and induction of tyrosine aminotransferase in rat liver. Endocr. Jpn., 29, 209-218.

Jungblut, P. W., A. Hughes, J. Gaues, E. Kallweit, I. Maschler, F. Paul and W. Sierralta (1979). Mechanism involved in the regulation of steroid receptor levels. J. Steroid Biochem., 11, 273278.

King, W. J. and G. L. Greene (1984). Monoclonal antibodies localize oestrogen receptor in the nuclei of target cells. Nature, 307, 745-747.

Korach, K. S. and E. B. Ford (1978). Estrogen action in the mouse uterus: An additional nuclear event. Biochem. Biophys. Res. Commun., 83, 327-333.

Lowry, O. H., N. J. Rosebrough, A. L. Farr and R. J. Randall (1951). Protein measurement with the Folin phenol reagent. J. Biol. Chem., 193, 265-275.

Mainwaring, W. P. I. (1975). Steroid hormone receptor: A survey. Vit. and Horm., 33, 223245.

Mester, J. and E. E. Baulieu (1975). Dynamics of oestrogen-receptor distribution between cytosol and nuclear fractions of immature ra: uterus after oestradiol administration. Biochem. 
J., 146, 617-623.

O'Malley, B. W., R. J. Schwarz and W. T. Schrader (1976). A review of regulation of gene expression by steroid hormone receptors. J. Steroid Biochem., 7, 1151-1159.

Sarff, M. and J. Gorski (1971). Control of estrogen binding protein concentration under basal conditions and after estrogen administration. Biochemistry, 10, 2557-2563.

Schmidt, T. J. and G. Litwack (1982). Activation of the glucocorticoid receptor complex. Physiol. Rev., 62, 1131-1192.

Schum, D. E. and T. E. Webb (1974). The in vivo equivalence of a cell-free system for RNA processing and transport. Biochem. Biophys. Res. Commun., 58, 354-360.

Van Doorn E. and N. Bruchovski (1978). Mechanism of replenishment of nuclear androgen receptor in rat ventral prostate. Biochem. J., 174, 9-16.

Welshones, W. V., M. E. Lieberman and J. Gorski (1984). Nuclear localization of unoccupied oestrogen receptors. Nature, 307, 747-749.

Wilson, L. J., J. Bamburg, S. Mizel, L. M. Grisham and K. M. Creswell (1974). Interaction of drugs with microtubule proteins. Fed. Proc. $33,158-166$. 